\title{
SIKAP REMAJA TERHADAP UPAYA PENCEGAHAN PENYEBARAN COVID19 PADA ORANG TANPA GEJALA (OTG) DI SURABAYA
}

\author{
Linda Prasetyaning Widayati ${ }^{1)}$, Ika Mustika ${ }^{2)}$ \\ Fakultas Psikologi dan Kesehatan, UIN Sunan Ampel Surabaya \\ email:linda.prasetyaning@gmail.com
}

\begin{abstract}
Abstrak
COVID-19 adalah penyakit yang disebabkan virus Corona jenis baru SARS-CoV-2. Penyakit ini telah menjadi pandemi sejak akhir 2019 dengan kasus yang terus bertambah. Salah satu pencegahan COVID-19 adalah dengan memakai masker. Kebijakan pemerintah mewajibkan semua orang termasuk remaja memakai masker jika beraktivitas di luar rumah. Kepatuhan remaja memakai masker sangat penting terutama karena kasus terkonfirmasi tanpa gejala masih cukup tinggi. Tujuan penelitian ini adalah untuk mengetahui hubungan gender terhadap sikap keharusan OTG memakai masker saat di luar rumah. Penelitian ini merupakan penelitian observasi analitik. Populasi penelitian ini adalah seluruh mahasiswa di UIN Sunan Ampel Surabaya. Teknik pengambilan sampel adalah dengan simple random sampling. Analisis data dilakukan dengan Koefisien Phi dan Cramer's V. Hasil penelitian ini yaitu terdapat hubungan yang signifikan p (0,023) antara gender dan sikap keharusan OTG memakai masker saat di luar rumah.
\end{abstract}

Kata kunci: sikap remaja, COVID-19, kasus terkonfirmasi tanpa gejala

\begin{abstract}
COVID-19 is a disease caused by SARS-CoV-2. This disease has been a pandemic since late 2019. One of the prevention of COVID-19 is a mask. Government policy requires all people including teenagers to wear masks. Teenagers' obedience in wearing masks is very important, because asymptomatic confirmed cases have enormous number. The purpose of this study is to determine the gender relationship to the attitude of asymptomatic confirmed cases to wear masks. This research was an analytical observational study. The population of this study were all students at UIN Sunan Ampel Surabaya. The sampling technique was simple random sampling. Data analysis was carried out with the contingency coefficients and Cramer's V. The results of this study were that there was a significant correlation $p(0.023)$ between gender and the obligatory attitude of asymptomatic confirmed case in wearing a mask outside.
\end{abstract}

Keywords : teenagers'attitude, COVID-19, asymptomatic case

\section{PENDAHULUAN}

Corona virus disease 19 atau dikenal dengan covid19 merupakan penyakit yang disebabkan coronavirus jenis baru (SARS-CoV-2) yang ditemukan pada akhir tahun 2019 di Wuhan China. Dalam waktu singkat, jumlah kasus COVID-19 terus mengalami peningkatan dan menyebar luas ke berbagai negara hingga pada tanggal 11 Maret 2020, WHO menetapkan COVID-19 sebagai pandemi. Sampai tanggal 7 November 2020 tidak kurang dari 217 negara telah terkena dampak COVID-19. Jumlah penderita COVID-19 mencapai 48 juta orang dengan angka kematian 2,5\% (WHO 2020b).

Di Indonesia, kasus COVID-19 sudah menyebar hampir di seluruh wilayah provinsi. Pada tanggal 7 November 2020 jumlah kasus mencapai 433.836 kasus dengan jumlah kematian 14.540 kasus (Komite Penanganan Covid-19 dan Pemulihan Ekonomi Nasional 2020). Jawa Timur merupakan provinsi dengan persentase kematian akibat covid-19 tertinggi di Indonesia yaitu 7,2\% dengan jumlah kasus terbanyak di kota Surabaya. Meskipun angka kematian secara keseluruhan rendah, namun penyakit ini dapat menular dengan cepat dan setiap orang rentan untuk terinfeksi.

Data WHO menunjukkan terdapat $80 \%$ orang tanpa gejala (OTG) pada kasus terkonfirmasi COVID19 (Menteri Kesehatan RI 2020b). Beberapa penelitian menyebutkan bahwa pasien tanpa gejala dapat menularkan virus tanpa disadari. Hal tersebut menjadi salah satu penyebab penyebaran virus SARS-CoV-2 (Kronbichler et al. 2020; Lai et al. 2020). Hasil pemeriksaan PCR pada pasien dengan gejala dan pasien tanpa gejala menunjukkan keduanya memiliki prognosis dan potensi tingkat penularan yang sama $(\mathrm{Li}$ G, Fan Y, Lai Y, Han T, Li Z, Zhou P, et al. Dalam (Rachman, Rusli, and Miftahussurur 2020). 
Penelitian Chao Yu dkk menunjukkan bahwa pasien terkonfirmasi covid19 yang berusia muda cenderung tidak menunjukkan gejala. Penelitian lain menunjukkan bahwa orang berusia 20 tahun kebawah kemungkinan $81,9 \%$ tidak menunjukkan gejala setelah terinfeksi virus sars-cov2 (Poletti et al. 2020; Yu et al. 2020). Oleh karena itu perlu adanya penerapan protokol kesehatan terhadap semua orang, terutama pada remaja, meskipun mereka tidak memiliki gejala terkait COVID-19. Dengan mobilitas remaja yang cenderung tinggi, tidak menutup kemungkinan jika mereka menjadi OTG yang bisa menyebarkan virus tanpa mereka sadari.

Salah satu upaya yang dapat mencegah penularan covid19 adalah dengan menggunakan masker. Sebagaimana aturan yang telah dikeluarkan Pemerintah dimana masyarakat dianjurkan untuk menggunakan masker meskipun dalam kondisi sehat(Menteri Kesehatan RI 2020a). Masker dapat mencegah penyebaran droplets ketika berbicara, bernyanyi, bersin atau pun ketika batuk. Karena ketersediaan masker medis yang terbatas, penggunaan masker kain dapat menjadi alternatif untuk mengurangi penularan virus melalui droplets. Masker kain masih bisa digunakan dengan tetap memperhatikan prosedur penggunaan masker serta tetap melaksanakan protokol kesehatan lainnya seperti mencuci tangan dengan sabun dan menjaga jarak dengan orang lain (Dwirusman 2020; WHO 2020a).

Kepatuhan masyarakat dalam menggunakan masker sangat menentukan dalam upaya mengurangi penyebaran COVID-19. Penelitian yang dilakukan di Jakarta menunjukkan bahwa sebanyak $83 \%$ responden memiliki pengetahuan yang baik, $70,7 \%$ responden memiliki sikap yang baik, serta $70,3 \%$ responden memiliki ketrampilan yang baik tentang pencegahan COVID-19. Salah satu ketrampilan yang diteliti merupakan kepatuhan responden dalam menggunakan masker secara konsisten (Utami, Mose, and Martini 2020). Namun, pada kenyataannya masih terdapat masyarakat yang tidak menggunakan masker dengan benar. Penelitian yang dilakukan oleh (Sagala and Maifita 2020) menunjukkan bahwa pemahaman dan kesadaran masyarakat untuk melakukan upaya pencegahan penyebaran COVID-10 masih rendah. Tingkat kepatuhan masyarakat juga rendah hal tersebut terlihat dari tidak adanya social distance, tidak memakai masker dan bergerombol atau berkerumun.

Penelitian sebelumnya menunjukkan bahwa pengetahuan dan sikap berpengaruh terhadap perilaku masyarakat dalam menggunakan masker (Sari and Atiqoh 2020; Veneranda Venny et al. 2020). Penelitian lain menunjukkan sebanyak 59\% responden perempuan menganggap COVID-19 sebagai permasalahan yang serius, sedangkan pada responden laki-laki sebanyak 48,7\%. Perempuan lebih peduli terhadap konsekuensi kesehatan COVID-19 dan lebih patuh terhadap protokol kesehatan (Galasso et al. 2020). Berdasarkan latar belakang tersebut, peneliti ingin mengetahui bagaimana hubungan gender dan sikap keharusan memakai masker pada kasus terkonfirmasi tanpa gejala (OTG) COVID-19 di Surabaya.

\section{METODE PENELITIAN}

Penelitian ini merupakan penelitian observasi analitik dengan pendekatan cross sectional. Populasi pada penelitian ini adalah mahasiswa UIN Sunan Ampel Surabaya dengan sampel sebanyak 188 mahasiswa. Pengambilan sampel dengan menggunakan teknik simpel random sampling. Pengumpulan data dilaksanakan dengan menyebarkan kuesioner terhadap sampel yang telah dipilih secara acak. Setelah data terkumpul, dianalisis menggunakan Koefisien Phi dan Cramer's V.

\section{HASIL DAN PEMBAHASAN}

Hasil penelitian menunjukkan bahwa mayoritas responden berusia kurang dari 20 tahun atau masih remaja. Walaupun secara statistik antara kedua kelompok hampir memiliki jumlah yang seimbang dan hanya berbeda $2 \%$. Mayoritas responden berjenis kelamin perempuan yaitu sebesar $76 \%$. Keseluruhan responden pernah mendengar tentang pandemi COVID-19. Internet merupakan sumber utama responden mendapatkan info tentang COVID-19 yaitu sebesar $55 \%$. Hal ini dikarenakan sebagian responden memiliki akses berupa teknologi smartphone dan internet. Mayoritas responden setuju bahwa masker merupakan APD sebagai upaya preventif pencegahan COVID-19. Namun terdapat $10 \%$ menyatakan tidak setuju dengan pernyataan tersebut. Sebagian besar responden (95\%) setuju agar OTG tetap memakai masker saat keluar rumah. Sementara sisanya menyatakan hal itu tidak perlu dilakukan. Sebanyak $11 \%$ responden menyatakan orang yang sehat tidak perlu memakai masker saat keluar rumah. Namun mayoritas tidak setuju dengan pernyataan tersebut. Sedangkan dalam aspek kepatuhan memakai masker, 94\% responden mengaku selalu memakai masker sebagai upaya pencegahan penularan COVID-19 sedangkan sisanya menyatakan kadang-kadang saja memakai masker. Jenis masker yang paling banyak digunakan adalah masker kain 2 atau 3 ply (55\%) sedangkan 3\% dari responden masih memakai masker scuba walaupun WHO sendiri sudah tidak merekomendasikan hal tersebut. 
Tabel 1. Karakteristik Responden

\begin{tabular}{|c|c|c|}
\hline Variabel & $\mathbf{n}$ & $\%$ \\
\hline \multicolumn{3}{|l|}{ Umur } \\
\hline a. $\quad<20$ & 97 & 52 \\
\hline b. $\quad \geq 20$ & 91 & 48 \\
\hline \multicolumn{3}{|l|}{ Jenis Kelamin } \\
\hline a. Laki-laki & 45 & 24 \\
\hline b. Perempuan & 143 & 76 \\
\hline Pernah mendengar tentang COVID-19 & 188 & 100 \\
\hline \multicolumn{3}{|l|}{ Sumber Informasi } \\
\hline a. Internet & 105 & 55 \\
\hline b. TV & 75 & 40 \\
\hline c. Orang Lain & 6 & 3 \\
\hline d. Koran & 1 & 1 \\
\hline e. Radio & 1 & 1 \\
\hline \multicolumn{3}{|c|}{$\begin{array}{l}\text { COVID-19 bisa dicegah dengan memakai } \\
\text { masker }\end{array}$} \\
\hline a. Setuju & 170 & 90 \\
\hline b. Tidak Setuju & 18 & 10 \\
\hline \multicolumn{3}{|l|}{ OTG sebaiknya tetap memakai masker } \\
\hline a. Setuju & 179 & 95 \\
\hline b. Tidak Setuju & 9 & 5 \\
\hline \multicolumn{3}{|c|}{$\begin{array}{l}\text { Orang sehat tidak perlu memakai masker saat } \\
\text { ke luar rumah }\end{array}$} \\
\hline a. Setuju & 19 & 11 \\
\hline b. Tidak Setuju & 169 & 89 \\
\hline \multicolumn{3}{|l|}{ Kepatuhan memakai masker } \\
\hline a. Selalu & 176 & 94 \\
\hline b. Kadang-kadang & 12 & 6 \\
\hline \multicolumn{3}{|l|}{ Jenis masker yang digunakan } \\
\hline a. Scuba & 6 & 3 \\
\hline b. Masker kain 1 ply & 22 & 12 \\
\hline c. Masker kain 2 atau 3 ply & 104 & 55 \\
\hline d. Masker medis & 56 & 30 \\
\hline
\end{tabular}

Sumber: Data Primer, 2020

Hasil tabulasi silang antara variabel jenis kelamin responden dan variabel sikap menunjukkan bahwa responden laki-laki yang setuju OTG perlu memakai masker adalah sebanyak 40 orang sedangkan responden perempuan dengan pendapat yang sama sebanyak 139 orang. Jumlah responden laki-laki yang tidak setuju OTG perlu memakai masker adalah 5 orang sedangkan responden perempuan dengan pendapat yang sama sebanyak 4 orang.

Responden yang mengikuti penelitian mayoritas berusia remaja dan berjenis kelamin perempuan. Remaja merupakan masa peralihan dari usia anak-anak ke usia dewasa. Pada usia remaja, sering terjadi krisis identitas, rasa penasaran yang tinggi dan masa ingin membuktikan diri. Dikatakan oleh (Amita 2018) tahap masa remaja diawali dengan munculnya harga diri yang kuat, rasa berani yang berlebihan dan rasa kegirangan yang sangat ekspresif. Hal ini juga berpengaruh dalam masa pandemi dimana harusnya remaja sedang dalam masa ingin bersosialisasi, berkawan atau bersahabat dengan teman sebayanya, namun terhalang akses untuk bertemu dikarenakan pembatasan sosial. Keterbatasan ini membuat remaja merasa sedih dan tertekan. Penelitian ini sesuai dengan (Jamaluddin 2020) yang menyatakan bahwa permasalahan individu yang menginjak remaja sering berkaitan dengan masalah penyesuainan diri yang tidak teratasi dengan baik. Kebanyakan remaja mengalihkan perhatian mereka kepada internet baik untuk main game, melihat video, chatting atau browsing setelah mengikuti school from home. 
Oleh sebab itu mayoritas responden mengetahui informasi tentang pandemi COVID-19 melalui internet (55\%). Menurut Asosiasi Penyelenggara Jasa Internet Indonesia dalam (Moudy and Syakurah 2020) pengguna internet terbanyak adalah generasi milenial yaitu 49,52\%. Di dalam penelitian tersebut dikemukakan bahwa perempuan lebih tertarik mencari informasi mengenai kesehatan dan agama di internet. Penelitian ini juga sesuai dengan (Veneranda Venny et al. 2020) yang menyatakan mayoritas responden $(62,2 \%)$ mendapatkan informasi tentang COVID-19 melalui internet.

Informasi yang memadai dapat meningkatkan pengetahuan responden terkait COVID-19. Penelitian sebelumnya menunjukkan bahwa pengetahuan dan sikap berpengaruh terhadap perilaku masyarakat dalam menggunakan masker(Sari and Atiqoh 2020; Veneranda Venny et al. 2020). Seluruh responden setuju bahwa masker merupakan salah satu APD untuk mencegah tertular COVID-19. Hal ini sesuai dengan penelitian (Moudy and Syakurah 2020)yang menyatakan $96 \%$ responden memakai APD berupa masker. Responden paling banyak menggunakan masker kain 2 atau 3 ply. Hal ini sesuai dengan penelitian (Theopilus et al. 2020)yang menyatakan jika terdapat kelangkaan masker medis, masker kain dapat menjadi alternatif untuk digunakan selama pandemi. Hal ini dikarenakan masker kain lebih ekonomis, sustainable, mudah didapatkan dan dapat digunakan berulangkali. Masker kain diharapkan mampu meminimalisir transmisi virus melalui droplet. Masker kain dapat digunakan berulangkali dengan memperhatikan prosedur dalam pencucianya (Dwirusman 2020). Penelitian serupa juga dikemukakan oleh (Firdayanti et al. 2020)yang menyatakan bahwa jenis masker yang dapat digunakan masyarakat saat berada di luar rumah adalah masker kain. Mayoritas responden menggunakan masker saat keluar rumah. Tingkat kepatuhan responden cukup tinggi walaupun ada 6\% responden yang mengaku kadang-kadang saja memakai masker. Hal ini sesuai dengan penelitian (Sari and Atiqoh 2020)yang menyatakan mayoritas responden patuh memakai masker, namun terdapat $25 \%$ responden yang masih tidak patuh. Mayoritas responden setuju dengan pernyataan OTG harus selalu memakai masker saat keluar rumah. Hal ini sesuai dengan penelitian (Diah et al. 2020)yang menyatakan bahwa orang yang beresiko tinggi harus dibatasi mobilisasinya hingga masa inkubasi. Selain itu upaya preventif yang wajib dilakukan adalah menggunakan masker bila berada di daerah beresiko dan padat, mencuci tangan, mengkonsumsi makanan sehat, dan berolahraga.

Tabel 2. Tabulasi Silang Variabel Jenis Kelamin dan Sikap Responden

\begin{tabular}{|c|c|c|c|}
\hline \multirow{2}{*}{ OTG } & \multicolumn{2}{|c|}{ Jenis Kelamin } & \multirow[t]{2}{*}{ Total } \\
\hline & Laki-laki & Perempuan & \\
\hline Setuju & 40 & 139 & 179 \\
\hline Tidak Setuju & 5 & 4 & 9 \\
\hline Total & 45 & 143 & 188 \\
\hline
\end{tabular}

Sumber : Data Primer, 2020.

Tabel 3. Hubungan Jenis Kelamin Responden dan Sikap Responden terhadap Kasus Terkonfirmasi Tanpa Gejala dalam Penggunaan Masker

\begin{tabular}{lllr}
\hline \multicolumn{2}{c}{ Symmetric Measures } & Value & Approx. Sig. \\
\hline Nominal by Nominal & Phi & -.166 & .023 \\
& Cramer's V & .166 & .023 \\
& Contingency & .164 & .023 \\
& Coefficient & & \\
\hline N of Valid Cases & & 188 & \\
\hline
\end{tabular}

Sumber: Data Primer, 2020.

Dari tabel 3 dapat disimpulkan bahwa nilai $\mathrm{p}$ value dari uji statistik Koefisien Phi dan Cramer's
$\mathrm{V}$ adalah sama yaitu 0,023 . Angka tersebut lebih kecil dari $\alpha(0,05)$ yang artinya terdapat hubungan 
antara jenis kelamin dan sikap responden terhadap kasus terkonfirmasi tanpa gejala dalam penggunaan masker.

Dalam pengujian statistik terdapat hubungan antara gender atau jenis kelamin dengan sikap dalam pernyataan OTG harus memakai masker saat keluar rumah. Nilai $\mathrm{p}$ value adalah 0,023 kurang dari $\alpha$. Penelitian ini sesuai dengan penelitian (Galasso et al. 2020)yang menyatakan bahwa dalam menghadapi pandemi COVID-19, terdapat perbedaan yang sangat besar antara lakilaki dan perempuan tentang dampak bahaya COVID-19 terhadap kesehatan, kepatuhan serta sikap setuju pada kebijakan kesehatan yang baru. Hal ini menjelaskan perbedaan prognosis penyakit COVID-19 dilihat dari segi gender. Perempuan cenderung memiliki tingkat kepatuhan yang tinggi dibanding laki-laki. Perempuan biasanya lebih berhati-hati menyikapi suatu masalah kesehatan. sedangkan laki-laki seringkali abai terhadap kepatuhan penerapan pencegahan COVID-19 sehingga di lapangan, pasien laki-laki cenderung lebih banyak dibanding pasien perempuan. Hal ini tidak sesuai dengan penelitian (Ednadita et al. 2020) yang menyatakan tidak ada perbedaan signifikan antara jenis kelamin terhadap self control dalam hal ini kepatuhan. Penelitian tersebut juga mengungkapkan bahwa kerentanan dan kematian COVID-19 amat berbeda jika dilihat dari perspektif gender, diluar variabel perbedaan genetik dan imunologi, ada tidaknya komorbid, perilaku dan pekerjaan. Penelitian lain menunjukkan bahwa jenis kelamin mempunyai hubungan yang signifikan dengan pengetahuan tentang pencegahan COVID-19. Perempuan memiliki pengetahuan yang lebih baik karena memiliki lebih banyak waktu untuk mencari informasi dan berdiskusi tentang pencegahan COVID-19. Pengetahuan yang baik mempengaruhi kepatuhan masyarakat dalam menggunakan masker untuk mencegah COVID-19 (Sari and Atiqoh 2020; Suryaatmaja, Devra Jovana Clarissa Wulandari 2020; Wulandari et al. 2020).

\section{KESIMPULAN DAN SARAN}

Dalam penelitian ini dapat disimpulkan bahwa terdapat hubungan gender terhadap variabel sikap "OTG harus memakai masker saat ke luar rumah".

\section{REFERENSI}

Amita, Diananda. (2018). "Psikologi Remaja Dan Permasalahannya." ISTIGHNA 1(1):116-33.
Diah, Handayani, Hadi Dwi Rendra, Isbaniah Fathiyah, Burhan Erlina, and Agustin Heidy. (2020). "Penyakit Virus Corona 2019." Jurnal Respirologi Indonesia 40(2).

Dwirusman, Cindy Gustavia. (2020). "Peran dan Efektivitas Masker dalam Pencegahan Penularan Corona Virus Disease 2019 (COVID-19)." Jurnal Medika Hutama 2(1):9.

Ednadita, Gloryka, Shierlen Octavia, Farah Safira Khairunnisa, and Isyah Rodhiyah. (2020). "Effects of Self-Control on Cheating Among Indonesian College Students." Indonesian Psychological Research. 2(2):87-95.

Firdayanti, Firdayanti, Anieq Mumthi, Ferawati Taherong, Zelna Yuni, Sitti Saleha, and A. Dian Diarfah. (2020). "Jurnal Abdimas Kesehatan Perintis Pencegahan Covid-19 Melalui Pembagian Masker di Kelurahan Romang Polong Kabupaten Gowa." Jurnal Abdimas Kesehatan Perintis. 2(1):53-57.

Galasso, Vincenzo, Vincent Pons, Paola Profeta, Michael Becher, and Sylvain Brouard. (2020). "Gender Differences in COVID-19 Attitudes and Behavior: Panel Evidence from Eight Countries." PNAS. 117(44).

Jamaluddin, Muhammad. (2020). "Model Penyesuaian Diri Mahasiswa Baru A New Student Adjusment Model." Indonesian Psychological Research.2(2):109-18.

Komite Penanganan Covid-19 dan Pemulihan Ekonomi Nasional. (2020). Data Sebaran Virus Covid-19 di Indonesia.

Kronbichler, Andreas, Daniela Kresse, Sojung Yoon, Keum Hwa Lee, Maria Effenberger, and Jae Il Shin. (2020). "Asymptomatic Patients as a Source of COVID-19 Infections: A Systematic Review and Meta-Analysis." International Journal of Infectious Diseases. 98:180-86.

Menteri Kesehatan RI. (2020a). Surat Keputusan Menteri Kesehatan Republik Indonesia Tentang Pedoman Pencegahan dan Pengendalian Coronavirus Disease 2019 (COVID-19). Vol. No. 01.07/MENKES/413/2020.

Moudy, Jesica and Rizma Adlia Syakurah. (2020). "Pengetahuan Terkait Usaha Pencegahan Coronavirus Disease ( COVID-19 ) Di Indonesia." Higeia Journal of Public Health 4(3):333-46. 
Poletti, Piero, Marcello Tirani, Danilo Cereda, Filippo Trentini, Giorgio Guzzetta, Giuliana Sabatino, Valentina Marziano, Ambra Castrofino, Francesca Grosso, Gabriele Del Castillo, Raffaella Piccarreta, Aida Andreassi, Alessia Melegaro, Maria Gramegna, Marco Ajelli, and Stefano Merler. (2020). Probabilty of Symptoms and Critical Disease after SARSCov-2 Infection.

Rachman, Brian Eka, Musofa Rusli, and Muhammad Miftahussurur. (2020). "The Hidden Vulnerability Of Covid-19 Observed From Asymptomatic Cases In Indonesia." Systematic Reviews in Pharmacy. 11(2):11.

Sagala, Sri Handayani and Yesi Maifita. (2020). "Hubungan Pengetahuan dan Sikap Masyarakat terhadap Covid-19: A Literature Review." 8.

Sari, Devi Pramita and Nabila Sholehah Atiqoh. (2020). "Hubungan Antara Pengetahuan Masyarakat Dengan Kepatuhan Penggunaan Masker Sebagai Upaya Pencegahan Penyakit COVID-19 Di Ngrongah.” Jurnal Ilmiah Rekam Medis Dan Informatika Kesehatan. 10.

Suryaatmaja, Devra Jovana Clarissa Wulandari, Imanuel Sri Mei. (2020). "Hubungan Tingkat Kecemasan Terhadap Sikap Remaja Akibat Pandemik Covid-19." Manuju: Malahayati Nursing Journal 2(September):820-29.

Theopilus, Yansen, Thedy Yogasara, Clara Theresia, and Johanna Renny Octavia. (2020). "Analisis Risiko Produk Alat Pelindung Diri ( APD ) Pencegah Penularan COVID-19 Untuk Pekerja Informal Di Indonesia." Jurnal Rekayasa
Sistem Industri. 9(2):115-34.

Utami, Ressa Andriyani, Ria Efkelin Mose, and Martini Martini. (2020). "Pengetahuan, Sikap dan Keterampilan Masyarakat dalam Pencegahan COVID-19 di DKI Jakarta." Jurnal Kesehatan Holistic. 4(2):68-77.

Veneranda Venny, Grishela, Khoris Yenniver Henrita, and Akbar Fawaid. (2020). Kajian Tingkat Pengetahuan Covid-19 Terhadap Sikap Dan Perilaku Pencegahan Penularan Infeksi Covid19 Pada Tenaga Kesehatan Di Puskesmas Sungai Durian Tahun 2020. Vol. 2.

WHO. (2020a). "Anjuran Mengenai Penggunaan Masker Dalam Konteks COVID-19."

WHO. (2020b). WHO Coronavirus Disease (COVID19) Dashboard. World Health Organ.

Wulandari, Anggun, Fauzie Rahman, Nita Pujianti, Ayu Riana Sari, Nur Laily, Lia Anggraini, Farid Ilham Muddin, Agus Muhammad Ridwan, Vina Yulia Anhar, Muhammad Azmiyannoor, and Diki Bima Prasetio. (2020). "Hubungan Karakteristik Individu Dengan Pengetahuan Tentang Pencegahan Coronavirus Disease 2019 Pada Masyarakat Di Kalimantan Selatan.” Jurnal Kesehatan Masyarakat indonesia. 15(1):42-46.

Yu, Chao, Miao Zhou, Yang Liu, Tinglin Guo, Chongyang Ou, Liye Yang, Yan Li, Dongliang $\mathrm{Li}$, Xinyu $\mathrm{Hu}$, Li Shuai, Bin Wang, and Zui Zou. (2020). "Characteristics of Asymptomatic COVID-19 Infection and Progression: A Multicenter, Retrospective Study." Virulence 11(1):1006-14. 